\title{
What to propose to treat post-viral non-conductive smell disorder in COVID- 19 ? - systematic review with meta-analysis
}

Klinger Vagner Teixeira da Costa ( $\nabla$ klingercostamcz@gmail.com )

Cesmac University Center https://orcid.org/0000-0003-1425-1348

Aline Tenório Lins Carnaúba

Cesmac University Center https://orcid.org/0000-0003-4100-6866

Katianne Wanderley Rocha

Cesmac University Center https://orcid.org/0000-0002-0577-5740

Kelly Cristina Lyra de Andrade

State University of Health Sciences of Alagoas (UNCISAL) https://orcid.org/0000-0002-2618-4958

Pedro de L. Menezes

State University of Health Sciences of Alagoas (UNCISAL) https://orcid.org/0000-0003-1999-5055

\section{Systematic Review}

Keywords: Non-conductive smell disorders, Olfactory disorders, Smell disorders, Covid-19, SARS-CoV-2, Olfactory training

Posted Date: June 30th, 2020

DOI: https://doi.org/10.21203/rs.3.rs-39175/v1

License: (c) (i) This work is licensed under a Creative Commons Attribution 4.0 International License. Read Full License 


\section{Abstract}

\section{Objective}

To conduct a systematic review with meta-analysis on the treatments for post-viral non-conductive olfactory disorder (NCSD) to be proposed for olfactory disorder in COVID-19.

\section{Study design}

Systematic review and meta-analysis with searches between June $10^{\text {th }}$ and $13^{\text {th }}, 2020$ in the databases: Medline via PubMed, Cochrane Clinical Trials, ScienceDirect, Lilacs, Scopus, Google Schoolar and Web of Science and gray literature. Inclusion criteria: (1) clinical trials with NCSD; (2) olfactory assessment before and after the intervention using a validated method; exclusion criteria: (1) NCSD from neurological causes; (2) studies unrelated to NCSD treatment; (3) duplicate publications. The quality of the studies was assessed by two independent researchers according to the Cochrane Collaboration recommendations.

\section{Results}

A total of thirteen clinical trials met the criteria: nine on drug treatments and four on olfactory training with four odors. In drug treatments, caroverine, vitamin A, insulin, pentoxifylline, alpha-lipoic acid and sodium citrate were evaluated. The meta-analysis (336 patients) identified, through the random effect analysis, a statistically significant improvement between the TDI score before and after the olfactory training was observed (SMD = 5.18; $95 \%$ confidence interval (Cl) [4.12, 6.23], $\mathrm{p}<0.00001)$.

\section{Conclusion}

Sodium citrate and olfactory training are therapeutic approaches to recover olfactory function in post-viral NCSD and can be considered considered for NCSD due to COVID-19; however, further clinical trials are needed to confirm the results evaluated and establish treatment protocols.

\section{Introduction}

Non-conductive smell disorder (NCSD) is characterized by not being associated with nasal obstruction. Its etiology is often difficult to be identified, and therefore, indicating the best treatment is a challenge. There are several etiologies for acquired NCSD, and the most common are post-viral, post-traumatic and neurological [1]. The post-viral NCSD is the most common one [2,3], with variable duration, and $70 \%$ of cases occurring by rhinovirus, influenza and parainfluenza viruses, respiratory syncytial virus, adenovirus and severe acute respiratory syndrome virus 2 (SARS-CoV-2) (4). Severity can vary from mild to severe, and it can be permanent [2].

In the last few months, an increasing number of cases of olfactory disorders (ODs) associated with the coronavirus disease 2019 (COVID-19) caused by SARS-CoV-2 has been observed [5]. Currently, ODs are recognized as part of the COVID-19 clinical feature, with the onset before the general symptoms/signs of COVID-19, and most often not associated with nasal obstruction or rhinorrhea as in other viral infections, that is, being clinically characterized as a NCSD [6-9]. The recovery of smell in COVID-19 occurs, in most cases, in the first two weeks after resolution of the disease, while $26.4 \%$ remain with ODs, and it is still unknown whether long-term recovery will occur [9].

Unfortunately, no effective standard therapy for NCSD of any etiology has been established, even at NCSD in COVID-19. Several drugs have been proposed, for example: corticosteroids (systemic, topical), zinc, theophylline, alpha-lipoic acid, caroverine, vitamin B and others [10-12]; however, the effectiveness of most of these treatments remains uncertain. On the other hand, it has been experimentally shown in animals and in clinical studies that olfactory training with different odors may improve olfactory function [13-15].

Improvement in the knowledge on a specific topic can be supported by systematic reviews (SR) with meta-analyzes. They identify, analyze and synthesize the best scientific evidence for best clinical practices, especially in the face of new clinical scenarios such as the current COVID- 19 pandemic and the significant increase in ODs cases, in which randomized controlled trials and precise recommendations for their treatment are still unavailable.

The objective of this SR with meta-analysis is to identify and analyze the best scientific evidence on the effectiveness of the treatments available for NCSD to propose the best therapeutic options for olfactory function recovery in the face of the increasing demand from patients with olfactory sequelae caused by COVID-19.

\section{Methods}

This systematic review (SR) with meta-analysis aimed to answer the following question: "Which drug therapies and/or olfactory therapies are most effective for treating patients with non-conductive smell disorder?", according to PICO strategy for research. This SR is in accordance with the items of the Preferred Reporting Items for Systematic Reviews and Meta-Analyzes Statement (PRISMA) [16]. The protocol was registered on June 8, 2020 in the International Prospective Register of Systematic Reviews - Prospero database (https://www.crd.york.ac.uk/PROSPERO/) under registration number CRD42020189452

\section{Search strategy}


The strategies aimed at a complete search, including descriptors (Medical Subject Headings - Mesh) and free terms in order to identify relevant articles within the proposed question. The following search strategy was developed: (anosmia OR loss smell OR smell loss OR olfactory dysfunction OR smell disorder OR olfactory disorders) AND (treatment OR corticoids OR acid, alpha lipoic OR alpha lipoic acid OR lipoic acid OR zinc chelated pentosan

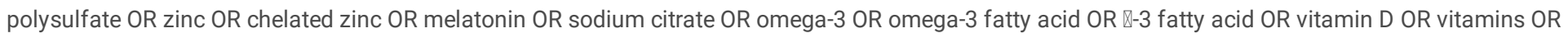
olfactory training OR olfactory therapy); this strategy was adapted to the databases. No language or date restrictions were applied. The complete search strategies are shown in the supplementary material (Appendix 1).

Between June $10^{\text {th }}$ and $13^{\text {th }}, 2020$, the following electronic databases were searched: Medline via PubMed, Cochrane Clinical Trials, ScienceDirect, Lilacs, Scopus, Google Schoolar and Web of Science, as well as the gray literature OpenGrey.eu, DissOnline, The New York Academy of Medicine and Research Gate. To avoid citation bias, there was no manual search for the included articles and specialists in the area were not contacted [17].

After the searches were performed, the references from each database were exported to Mendeley® (https://www.mendeley.com/) to identify duplicate articles, promote greater reliability in the selection and proceed to the eligibility criteria step.

\section{Eligibility criteria}

The following inclusion criteria were considered: (1) clinical trials with individuals diagnosed with non-conductive smell disorders; (2) quantification of the degree of olfactory capacity through a validated method before and after the intervention. The exclusion criteria were considered: (1) studies on neurological olfactory disorders; (2) studies in which the intervention was not related to the treatment of the olfactory disorder; (3) duplicate publications.

\section{Data extraction}

The article search was performed by two evaluators. The titles and abstracts of the retrieved articles were independently assessed by two researchers who were not blind to the authors or the journal titles. The full versions of potentially eligible articles were retrieved for further assessment, carried out in three phases:

1. Identification and reading of titles in different electronic databases. Articles that clearly did not meet any of the inclusion or exclusion criteria were excluded.

2. Reading of abstracts of the studies selected in the first phase. Likewise, articles that clearly did not meet any of the inclusion or exclusion criteria were excluded.

3. The studies which were not excluded in these first two phases were read in full for the selection of articles to be included in this SR with meta-analysis.

The main data of each article was fully collected and inserted into a database structured in the Microsoft Office Excel $2010 \AA$ software. There were no divergences in the evaluators' analysis. A standard form for data storage was created based on the model adopted by Cochrane [18]. For better presentation of the results, we decided to consider the following variables of the selected articles: Title, author, sample size ( $\mathrm{N}$ ), age, olfactory evaluation method, NCSD causes and treatment. The outcomes sought in the studies were both the treatments proposed for olfactory disorders and the evidence of their effectiveness.

\section{Quality assessment of studies}

The quality of the studies was assessed according to the recommendations on the Cochrane Collaboration handbook [19]. Two investigators independently assessed the quality of the studies in the following categories: random sequence generation, allocation concealment, blinding of participants and professionals, blinding of outcome assessment, incomplete outcomes, selective outcome reporting and other sources of bias.

After these assessments, the selected studies were submitted to a statistical analysis to verify the possibility of a meta-analysis. This analysis combines and summarizes the results of several studies, thus increasing the accuracy and power of the evidence of the results.

\section{Data analysis}

The improvement in olfactory function after using the proposed treatment was analyzed. Statistical heterogeneity among the studies and inconsistency were tested through Cochran's Q test and $\mathrm{I}^{2}\left(\mathrm{I}^{2}<25 \%\right.$ : homogeneity; $25 \% \leq \mathrm{I}^{2}<50 \%$ : low heterogeneity; $50 \% \leq \mathrm{I}^{2}<75 \%$ : moderate heterogeneity and $\mathrm{I}^{2}>75 \%$ : high heterogeneity) [20], respectively. A value of $p<0.10$ was considered statistically significant. When necessary, the characteristics of the study considered as potential sources of heterogeneity were included in a subgroup analysis. In addition, in case of high heterogeneity, the studies were removed, one by one, to identify which one was the source of high heterogeneity. The pooled results were meta-analyzed using a fixed effects model if the studies were homogeneous or of low heterogeneity; a random effect model was used if the studies showed moderate or high heterogeneity. An a < 0.05 value was considered statistically significant. When adequate data for analysis was impossible, Cochrane's recommendations were followed.

All analyzes were performed using RevMan software (version 5.3, The Nordic Cochrane Center, The Cochrane Collaboration, Copenhagen, Denmark, 2014).

\section{Results}


In the first phase of this SR with meta-analysis, 5,743 articles were found in seven databases, but none in the gray literature. After excluding 304 duplicate studies, 5,439 were selected for reading titles and abstracts. 5,420 were excluded according to the established selection criteria (1,829 studies with patients with ODs associated with nasal obstruction or neurological causes; 1,220 due to missing information on treatments; 1,190 without olfactory data; 512 literature reviews; 668 experimental studies; and one Cohort), and 19 articles were selected for full reading. After the reading, six articles were excluded because their samples were composed of patients with obstructive nasal disease (table 1). However, of the 13 studies included in the qualitative analysis (table 2), five studies were unique in their treatment [10, 21-24] and four did not have enough data for quantitative analysis (meta-analysis) [25-28]. Thus, four studies were selected for the meta-analysis involving 336 patients [29-32] (table 3). The entire article selection process is described in figure 1, which shows the PRISMA flow diagram for inclusion.

\section{Risk of bias assessment}

Of the 13 included articles, three studies specified the blinding methods of participants and professionals, as well as the blinding of outcome assessors providing enough information to allow judgment [22,24,27].

Most studies presented a risk of uncertain bias, mainly due to the impossibility of judging by the following criteria: random sequence generation and allocation concealment, denoting an important selection bias; and many studies presented risk of uncertain bias for the item blinding of participants/professionals and for the item blinding of outcome assessments, denoting measurement bias.

The study by Reden et al. (2017), reports how Vitamin A was administered in the groups as a limitation [24]; the study by Poletti et al. (2016), states that possible differences in solubility may interfere in the effect of the molecular weight of odors [30]. The quality analysis of the included articles is shown in table 4.

\section{Data analysis}

Regarding the general characteristics of the articles included in the qualitative analysis, seven studies were conducted in Germany and six in other countries (Table 1). Outcome measures were determined by symptom scores and objective methods of olfactory testing - with the Sniffin 'Sticks test as the most common test used in the studies. Ten studies compared the mean TDI score ("T" - threshold, "D" - discrimination, "I" - identification) before and after drug treatment in NCSD (total of six drugs) [10, 21-28], while four compared the mean TDI score before and after olfactory training in NCSD [29-32] (table 3). Of the studies with drug treatment, five were the only ones for the drug they proposed to analyze (oral caroverine, oral vitamin A, intranasal insulin, intravenous pentoxifylline and oral lipoic acid) [10,21-24] and four were on intranasal sodium citrate [26-28]; however, studies with sodium citrate did not provide sufficient pre- and post-treatment data for meta-analysis.

\section{Drug treatments for NCSD.}

\section{1- Caroverine}

In a randomized controlled study, Quint et al. investigated the use of quinoxaline derivative caroverine to treat various sensorineural ODs, including postviral NCSD [21]. A total of 77 patients with NCSD were included in the study, 51 received oral caroverine for 4 weeks (120 mg/day) and 26 controls for 1 month. Olfactory sensitivity was assessed before and after treatment, and patients were blinded. The tests included the assessment of the odor threshold of n-butanol (BTT) and odor identification (Sniffin'Sticks test). Caroverine improved the thresholds $(p<0.005)$ and odor identification $(p<0.042)$ in patients with anosmia, and significantly improved the ability to identify odors $(p<0.041)$ in patients with hyposmia.

The results showed that 13 of the 35 patients with anosmia in the treatment group improved the thresholds in BTT (6 responders had post-viral NCSD). Transitory nausea was reported by two patients and transitory headache by one patient. No severe adverse effects were reported.

\section{2-Vitamin A}

In a double-blind, controlled and randomized clinical trial with oral vitamin A in 52 patients with post-viral and post-traumatic NCSD, 26 participants received oral vitamin $A(10,000 \mathrm{IU} /$ day) and 26 received placebo for three months [24]. The olfactory function was assessed through the Sniffin'Sticks test in which the patients were blinded, and through a standardized questionnaire. Forty-four percent of patients reported smell recovery, and $29 \%$ showed significant improvement in olfactory function. However, there was no significant difference between the results of patients who received oral vitamin A or placebo.

\section{3- Insulin}

In a double-blind, controlled and randomized clinical trial with intranasal insulin in 38 patients with NCSD, 19 participants received intranasal insulin (40 IU), and 19 received placebo (saline) twice a week for four weeks [22]. Olfactory function was assessed through the Connecticut Chemosensory Clinical Research Center (CCCRC) test at onset and four weeks after treatment.

The CCCRC test score in the intervention group was significantly higher in comparison with the placebo group $(p=0.01)$. Intranasal insulin appears to be effective in the treatment of NCSD.

\section{4- Alpha-lipoic acid}


A prospective, uncontrolled clinical trial investigated 23 patients with post-viral NCSD treated with oral alpha-lipoic acid. The administered regimen included alpha-lipoic acid ( $600 \mathrm{mg} /$ day), for approximately 4.5 months [10]; there was no control group. The olfactory function was assessed through the Sniffin'Sticks test and the patients were blinded. Of the treated patients, $26 \%$ showed a moderate improvement in the TDI score (1.5 $\leq$ TDI < 5.5 points), and $35 \%$ showed a notable improvement (TDI $\geq 5.5)$. The recovery of olfactory function appeared to be more evidenced $(t=2.56[p=0.018])$ in younger patients than in patients over 60 years (the age of 60 was the average of the group). Oral alpha-lipoic acid appears to be effective in the treatment of postviral NCSD.

\section{5- Pentoxifylline}

In a longitudinal study with pentoxifylline to treat diseases of the inner ear, 19 patients received intravenous pentoxifylline (400mg/day) [23]. Olfactory function was assessed through the Sniffin'Sticks test before and after drug treatment. After pentoxifylline administration, patients demonstrated a decrease in the odor threshold towards lower odor concentrations $(p=0.01)$ and was increased in younger patients than in the elderly adults.

\section{6-Sodium citrate}

In the first randomized clinical trial by Whitcroft et al. (2016), with 57 patients with NCSD (post-viral, post-traumatic or idiopathic), one nostril was treated with sodium citrate $(3.5 \mathrm{~g} / 140 \mathrm{ml})$ and the other nostril with $0.9 \%$ sodium chloride [25]. The Sniffin 'Sticks test was performed separately in each nostril. The patients were blinded to the side of the sodium citrate application. Compared with placebo, there was a significant improvement in the identification scores of participants with post-viral NCSD after treatment with sodium citrate. In the second clinical trial by Whitcroft et al. (2016) with 49 patients with post-viral NCSD, one nostril was treated with sodium citrate $(3.5 \mathrm{~g} / 140 \mathrm{ml})$ and the other nostril with $0.9 \%$ sodium chloride [28]. The Sniffin 'Sticks test was performed separately in each nostril. The patients were blinded to the side of the sodium citrate application. There was a statistically significant improvement in olfactory thresholds after treatment with sodium citrate compared with placebo in all patients (mean improvement of $0.87 \pm 2.68$ points, $p$ $=0.04$ ) and in the analysis of subgroups in those with hyposmia (mean improvement of $1.15 \pm 2.37$ points, $p=0.02$ ).

In a randomized clinical trial with 31 patients with NCSD (post-viral, post-traumatic or idiopathic), each patient's olfaction was assessed twice [26]. On the first day, olfaction was tested before and after intranasal administration of $0.9 \%$ sodium chloride in each nostril; on the third day, the same patients olfaction was tested before and after intranasal administration of sodium citrate $(3.5 \mathrm{~g} / 140 \mathrm{ml})$. The olfactory function was assessed through the Sniffin'Sticks test. Thirty patients (96.8\%) improved their scores in less than an hour after using sodium citrate.

In a randomized, double-blind clinical trial with 55 patients with NCSD (post-viral, post-traumatic or idiopathic), 31 participants received intranasal sodium citrate $(3.5 \mathrm{~g} / 140 \mathrm{ml})$, and 24 received $0.9 \%$ sodium chloride [27]. The olfactory thresholds were assessed through a test using phenylethyl alcohol (roses), 1-butanol (pear), acetic acid (vinegar) and eucalyptol (menthol), previously validated by the same authors. A significant effect was observed in the intervention group for phenylethyl alcohol and 1-butanol and eucalyptol when compared to control group $(p<0.05)$; $32 \%$ of patients treated with sodium citrate showed an improvement in sensitivity to some of the odors.

Thus, intranasal sodium citrate appears to be effective in the treatment of NCSD, including post-viral cases, with a temporary effect lasting between 30 and 60 minutes.

\section{Effect of olfactory training on NCSD}

On the topic olfactory training, four articles and 336 patients were selected; the articles studied olfactory training with four odors: phenyl ethanol (rose), menthol (mint), citronellal (lemon) and eugenol (clove), twice a day (morning and night), instructing the patient to smell each substance for 10 seconds, and 10 seconds of interval between them.

The research carried out the meta-analysis of the four articles that performed olfactory training for at least three months; the improvement in olfaction (increase in mean TDI score) after olfactory training (SMD $=5.99 ; 95 \%$ confidence interval $(\mathrm{Cl})[4.68,7.31]$, p < 0.00001$)$ was statistically higher than in pretraining (fig. 2). Considering the causes of NCSD in these articles, all studies had patients with sequelae after viral infection, and in one of them, the sample was also composed of patients with post-traumatic sequelae and idiopathic causes [32]; therefore, a subgroup meta-analysis was carried out with the three studies whose sample was composed with only post-viral NCSD cases and with the data referring to the group with post-viral NCSD from the study with mixed sample; this subgroup meta-analysis also showed an improvement in olfaction (increased mean TDI score) after olfactory training (SMD = 5.18; $95 \%$ confidence interval $(\mathrm{Cl})[4.12,6.23], \mathrm{p}<0.00001)$ was statistically higher than in the pre-training (fig.3); the data from the used olfactory training and the results can be seen in table 2 . The olfactory training improved the mean TDI score in all studies, and especially in patients with post-viral NCSD.

\section{Discussion}

The current SR with meta-analysis was performed to identify and analyze the best scientific evidence on the effectiveness of treatments available for NCSD in order to propose the best therapeutic options to recover olfactory function due to the increasing number of patients with olfactory sequelae caused by COVID-19. The results of this review can be classified into two lines of treatment: one with administration of drugs and the other with olfactory training.

Regarding the drug treatment, nine articles and 401 patients were selected; the articles studied six substances, two of them with intranasal use (insulin and sodium citrate); three with oral via (caroverine, alpha-lipoic acid and vitamin A) and intravenous pentoxifylline. However, only sodium citrate was found in 
more than one article (total of four), while the other substances were studied by unique studies. Regarding the four studies on sodium citrate, the data were insufficient to perform a meta-analysis and, therefore, remained only in the qualitative analysis.

Oral caroverin $(120 \mathrm{mg} / \mathrm{day})$ for one month was effective in improving the threshold and odor identification in post-viral NCSD; however, patients reported transitory nausea during treatment. Caroverine may modulate the activity of mitral cells in the olfactory bulb through its antagonism at N-methyl-Daspartate (NMDA) receptors improving the detection of olfactory-induced activation [33]. Other mechanisms may include competitive antagonism at both alpha-amino-3-hydroxy-5-methylisoxazole-4-proprionic acid (AMPA) receptor sites and, at higher concentrations, at the NMDA receptor's glycine site [34]. As excitation of granule cells through mitral-tufted cells is strongly NMDA receptor-dependent, blocking of NMDA receptors might also reduce g-aminobutyric acid negative feed- back onto mitral and tufted cells, which in turn might increase net excitation in the olfactory bulb [33].

Intranasal insulin (40 IU) for four weeks improved olfactory function in patients with NCSD, but studies with groups of NCSD specifically post-viral are missing. The mechanism of intranasal insulin is quite clear, as the olfactory bulb is the largest place for the transformation of intranasal insulin to the brain [35].

Alpha-lipoic acid $(600 \mathrm{mg} /$ day) for about 4.5 months was shown to be effective, mainly in younger patients with post-viral NCSD. It stimulates the expression of nerve growth factor, substance $\mathrm{P}$, and neu-ropeptide $\mathrm{Y}$ [36-38]; it also has potent antioxidative effects and neuroprotective capabilities indicating that lipoic acid is suited to treat neural damage involving free radicals [22].

Pentoxifylline (400mg/day) has been shown to improve the olfactory threshold, but there are no further studies on its use specifically in post-viral NCSD. Because pentoxifylline is an unespecific phosphodiesterases (PDE) inhibitor, it can result in increased intracellular concentration of cAMP; elevated cAMP level leads to increased response of olfactory sensory neurons to chemical stimuli [39].

Intranasal sodium citrate (3.5g/140ml, pH 7.4, osmolarity 298) was the most studied substance, and in all studies there was an improvement in olfactory function in patients with post-viral NCSD; however, it has a transitory effect which lasts about 30-60 minutes. Sodium citrate acts as sequestrant, binding to free $\mathrm{Ca}^{++}$ions in the nasal mucus and therefore diminishing mucosal $\mathrm{Ca}^{++}$; it leads to amplified receptor responses, improving olfactory function [26].

Regarding olfactory training, all studies had samples composed of patients with post-viral NCSD; however, the study by Hummel et al. (2009), did not specify the number of patients in the sample with post-viral, post-traumatic or idiopathic NCSD [32]. The number of women was higher than that of men and the average age of the groups was over 50 years. NCSD degrees were not mentioned in all studies, but all groups submitted to olfactory training intervention, for at least three months, showed improvement in olfactory function. The results of the meta-analyzes showed that olfactory training is effective in the rehabilitation of olfactory function in cases of post-viral NCSD.

Electrophysiological studies have shown that repeated exposure to odors in humans can produce increased electrical potential records from the olfactory epithelium [40]. However, the positive effect of olfactory training may not only be related to peripheral factors, but may possibly be attributed to central changes [14]. A study shows that there are representations for odor categories in the olfactory bulb [41]; thus, the use of different odor categories in a training scheme can induce more prolonged activation of olfactory function.

The olfactory function has the ability to recover when subjected to repeated short-term exposure to odors due to an increase in the growth of neurons in the olfactory receptor and an increased expression of receptors in response to odor exposure [42]. Therefore, olfactory training should produce a general increase in olfactory function.

Therefore, in drug treatment, intranasal sodium citrate can be used to minimize the olfactory limitation in NCSD, especially during meals, as a medication with topical effect and with transitory duration. Thus, sodium citrate and olfactory training appear as therapeutic proposals to recover olfactory function in post-viral NCSD, such as in COVID-19, requiring additional clinical trials to confirm the evaluated results and establish treatment protocols.

\section{Limitations}

This systematic review with meta-analysis has some limitations. Although electronic searches were performed in multiple databases, some relevant studies may have been overlooked in our search strategy. Although all of the included studies are clinical trials, many showed uncertain bias, mainly due to the possibility of judging the criteria: random sequence generation and allocation concealment, blinding of participants and outcome assessors, promoting a lesser probability to determine a cause-effect relationship between events. The studies were also conducted across different countries, which can lead to different results in olfactory tests due to sociocultural differences. Also, the pooled data were limited by a small number of included studies and small sample size and, therefore, more prone to bias. Overall, these limitations should be considered to indicate a treatment for NCSD due to COVID-19.

\section{Conclusion}

This study demonstrated that there is scientific evidence about the efficacy of drug treatment and olfactory training in recovery of olfactory function in post-viral non-conductive smell disorder.

\section{Conflicts Of Interest}

The authors declare no conflicts of interest. 


\section{References}

1. Suzuki M, Saito K, Min WP, Vladau C, Toida K, Itoh H, et al (2007) Identification of viruses in patients with postviral olfactory dysfunction. Laryngoscope 117:272-277.

2. Harless L, Liang J (2016) Pharmacologic treatment for postviral olfactory dysfunction: a systematic review. Int Forum Allergy Rhinol 6:760-767.

3. Deems DA, Doty RL, Settle RG, Moore-gillon V, Shaman P, Mester AF, et al (1991) Smell and Taste Disorders, A Study of 750 Patients From the University of Pennsylvania Smell and Taste Center. Arch Otolaryngol Head Neck Surg 117:519-528.

4. Butowt R, Bilinska K (2020) SARS-CoV-2: Olfaction, Brain Infection, and the Urgent Need for Clinical Samples Allowing Earlier Virus Detection. ACS Chem Neurosci 11:1200-1203.

5. Guan W, Ni Z, Hu Y, Liang W, Ou C, He J, et al (2020) Clinical Characteristics of Coronavirus Disease 2019 in China. N Engl J Med 382:1708-1720.

6. Mao L, Wang M, Chen S, He Q, Chang J, Hong C, et al (2020) Neurological Manifestations of Hospitalized Patients with COVID-19 in Wuhan, China: A Retrospective Case Series Study. JAMA Neurol [ahead of print].

7. Lechien JR, Chiesa-Estomba CM, De Siati DR, Horoi M, Le Bon SD, Rodriguez A, et al (2020) Olfactory and gustatory dysfunctions as a clinical presentation of mild-to-moderate forms of the coronavirus disease (COVID-19): a multicenter European study. Eur Arch Oto-Rhino-Laryngology 1-11 [Epub ahead of print]. http://www.ncbi.nlm.nih.gov/pubmed/32253535

8. Moein ST, Hashemian SMR, Mansourafshar B, Khorram-Tousi A, Tabarsi P, Doty RL (2020) Smell dysfunction: a biomarker for COVID-19. Int Forum Allergy Rhinol [Epub ahead of print].

9. Yan CH, Faraji F, Bs DPP, Boone CE, Deconde AS (2020) Association of Chemosensory Dysfunction and Covid-19 in Patients Presenting with Influenzalike Symptoms. Int Forum Allergy Rhinol. [Epub ahead of print].

10. Hummel T, Heilmann S, Hüttenbriuk K-B (2002) Lipoic acid in the treatment of smell dysfunction following viral infection of the upper respiratory tract. Laryngoscope 112:2076-2080.

11. Heilmann S, Just T, Göktas Ö, Hauswald B, Hüttenbrink KB, Hummel T (2004) Untersuchung der wirksamkeit von systemischen bzw. topischen kortikoiden und vitamin B bei riechstörungen. Laryngorhinootologie 83:729-734.

12. Heilmann S, Huettenbrink K-B, Hummel T (2004) Local and systemic administration of corticosteroids in the treatment of olfactory loss. Am J Rhinol 18:29-33.

13. Youngentob SL, Kent PF (1995) Enhancement of odorant-induced mucosal activity patterns in rats trained on an odorant identification task. Brain Res 670:82-88.

14. Livermore A, Laing DG (1996) Influence of Training and Experience on the Perception of Multicomponent Odor Mixtures. J Exp Psychol Hum Percept Perform 22:267-277.

15. Patel ZM, Wise SK, DelGaudio JM (2017) Randomized Controlled Trial Demonstrating Cost-Effective Method of Olfactory Training in Clinical Practice: Essential Oils at Uncontrolled Concentration. Laryngoscope Investig Otolaryngol 2:53-56.

16. Moher D, Liberati A, Tetzlaff J, Altman DG, Group TP (2009) Preferred Reporting Items for Systematic Reviews and Meta-Analyses: The PRISMA Statement. PLoS One 6:1-7.

17. Sterne J, Egger M, Moher D (2011) Adressing reporting biases. In: Hoggins J, Green S (ed) Cochrane Handbook for Systematic Reviews of Interventions Version 5.1.0.

18. Higgins J, Deeks J (2011) Selecting studies and collecting data. In: Higgins J, Green S (ed) Cochrane Handbook for Systematic Reviews of Interventions Version 510.

19. Higgins J, Altman D, Sterne J (2011) Assessing risk of bias in included studies. In: Higgins J, Green S (ed) Cochrane Handbook for Systematic Reviews of Interventions Version 510.

20. Higgins PTJ, Thompson SG, Deeks JJ, Altman DG (2006) Measuring inconsistency in meta-analyses. BMJ Open 27:557-560.

21. Quint C, Temmel AFP, Hummel T, Ehrenberger K (2002) The quinoxaline derivative caroverine in the treatment of sensorineural smell disorders: a proofof-concept study. Acta Otolaryngol 122:877-881.

22. Rezaeian A (2018) Effect of Intranasal Insulin on Olfactory Recovery in Patients with Hyposmia: A Randomized Clinical Trial. Otolaryngol neck Surg 158:1134-1139.

23. Gudziol V, Hummel T (2009) Effects of pentoxifylline on olfactory sensitivity: A postmarketing surveillance study. Arch Otolaryngol - Head Neck Surg 135:291-295.

24. Reden J, Lill K, Zahnert T, Haehner A, Hummel T (2012) Olfactory function in patients with postinfectious and posttraumatic smell disorders before and after treatment with vitamin A: A double-blind, placebo-controlled, randomized clinical trial. Laryngoscope 122:1906-1909.

25. Whitcroft KL, Merkonidis C, Cuevas M, Haehner A, Philpott C, Hummel T (2016) Intranasal sodium citrate solution improves olfaction in post-viral hyposmia. Rhinology 54:368-373.

26. Panagiotopoulos G, Naxakis S, Papavasiliou A, Filipakis K, Papatheodorou G, Goumas P (2005) Decreasing nasal mucus Ca++ improves hyposmia. Rhinology 43:130-134.

27. Philpott CM, Erskine SE, Clark A, Leeper A, Salam M, Sharma R, et al (2017) A randomised controlled trial of sodium citrate spray for non-conductive olfactory disorders. Clin Otolaryngol 42:1295-1302. 
28. Whitcroft KL, Ezzat M, Cuevas M, Andrews P, Hummel T (2017) The effect of intranasal sodium citrate on olfaction in post-infectious loss: results from a prospective, placebo-controlled trial in 49 patients. Clin Otolaryngol 42:557-563.

29. Qiao X-F, Bai Y-H, Wang G-P, Li X, Zheng W (2020) Clinical effects of two combinations of olfactory agents on olfactory dysfunction after upper respiratory tract infection during olfactory training. Rev Assoc Med Bras 66:18-24.

30. Poletti SC, Michel E, Hummel T (2017) Olfactory training using heavy and light weight molecule odors. Chemosens Percept 46:343-351.

31. Konstantinidis I, Tsakiropoulou E, Bekiaridou P, Kazantzidou C, Constantinidis J (2013) Use of olfactory training in post-traumatic and postinfectious olfactory dysfunction. Laryngoscope 123:E85-E90.

32. Hummel T, Rissom K, Reden J, Hähner A, Weidenbecher M, Hüttenbrink KB (2009) Effects of olfactory training in patients with olfactory loss. Laryngoscope 119:496-499.

33. Aroniadou-Anderjaska V, Ennis M, Shipley MT (1999) Dendrodendritic recurrent excitation in mitral cells of the rat olfactory bulb. J Neurophysiol 82:489-494.

34. Obstreicher E, Arnold W, Ehrenberger K, Felix D (1999) New approaches for inner ear therapy with glutamate antagonists. Acta Otolaryngol 119:174178.

35. Renner DB, Svitak AL, Gallus NJ, Ericson ME, Frey WH, Hanson LR (2012) Intranasal delivery of insulin via the olfactory nerve pathway. J Pharm Pharmacol 64:1709-1714.

36. Hounsom L, Corder R, Patel J, Tomlinson DR (2001) Oxidative stress participates in the breakdown of neuronal phenotype in experimental diabetic neuropathy. Diabetologia 44:424-428.

37. Hounsom L, Horrobin DF, Tritschler H, Corder R, Tomlinson DR (1998) A lipoic acid-gamma linolenic acid conjugate is effective against multiple indices of experimental diabetic neuropathy. Diabetologia 41:839-843.

38. Garrett NE, Malcangio M, Dewhurst M, Tomlinson DR (1997) a-Lipoic acid corrects neuropeptide deficits in diabetic rats via induction of trophic support. Neurosci Lett 222:191-194.

39. Nakamura T (2000) Cellular and molecular constituents of olfactory sensation in vertebrates. Comp Biochem Physiol - A Mol Integr Physiol 126:1732.

40. Wang L, Chen L, Jacob T (2004) Evidence for peripheral plasticity in human odour response. J Physiol 554:236-244.

41. Auffarth B, Gutierrez-Galvez A, Marco S (2011) Continuous spatial representations in the olfactory bulb may reflect perceptual categories. Front Syst Neurosci 5:1-8.

42. Haehner A, Tosch C, Wolz M, Klingelhoefer L, Fauser M, Storch A, et al (2013) Olfactory training in patients with Parkinson's disease. PLoS One 8:1-7.

\section{Tables}


Table 1 Complete texts excluded from the analysis.

\begin{tabular}{|c|c|c|c|}
\hline Author & Country & Year & Exclusion criteria \\
\hline $\begin{array}{l}\text { Heilman et } \\
\text { al. }\end{array}$ & Germany & 2004 & $\begin{array}{l}\text { Patients with } \\
\text { obstructive nasal } \\
\text { disease }\end{array}$ \\
\hline $\begin{array}{l}\text { Heilman et } \\
\text { al. }\end{array}$ & Germany & 2004 & $\begin{array}{l}\text { Patients with } \\
\text { obstructive nasal } \\
\text { disease }\end{array}$ \\
\hline $\begin{array}{l}\text { Schriever et } \\
\text { al. }\end{array}$ & Germany & 2011 & $\begin{array}{l}\text { Patients with } \\
\text { obstructive nasal } \\
\text { disease }\end{array}$ \\
\hline Patel et al. & United States & 2017 & $\begin{array}{l}\text { Patients with } \\
\text { obstructive nasal } \\
\text { disease }\end{array}$ \\
\hline Seo et al. & South Korea & 2009 & $\begin{array}{l}\text { Patients with } \\
\text { obstructive nasal } \\
\text { disease }\end{array}$ \\
\hline Stenner et al. & Germany & 2008 & $\begin{array}{l}\text { Patients with } \\
\text { obstructive nasal } \\
\text { disease }\end{array}$ \\
\hline
\end{tabular}

Table 2 Clinical trials selected according to the inclusion and exclusion criteria established in the systematic review.

\begin{tabular}{|c|c|c|c|c|c|}
\hline Study (year) & Country & Treatment & $\mathrm{N}$ & Olfactory Test & Results \\
\hline Quint et al. $(2002)^{21}$ & Austria & $\begin{array}{l}\text { Caroverine } \\
\text { (oral) }\end{array}$ & 77 & Sniffin`Sticks olfactory test (TDI score*) & Caroverine appears to be effective for NCSD** treatment. \\
\hline Rezaeiam $(2018)^{22}$ & Iran & \begin{tabular}{|l|l} 
Insulin \\
(intranasal)
\end{tabular} & 38 & CCCRC test*** & $\begin{array}{l}\text { There was an improvement in smell compared to the placebo group ( } \mathrm{p} \\
=0.01 \text { ) in patients with NCSD**. }\end{array}$ \\
\hline $\begin{array}{l}\text { Gudziol and Hummel } \\
(2009)^{23}\end{array}$ & Germany & $\begin{array}{l}\text { Pentoxifylline } \\
\text { (intravenous) }\end{array}$ & 19 & Sniffin'Sticks test & $\begin{array}{l}\text { There was an improvement in smell }(p=0.01) \text { and more evidenced in } \\
\text { younger patients than in the elderly. }\end{array}$ \\
\hline $\begin{array}{l}\text { Hummel, Heilmann } \\
\text { and Hüttenbriuk } \\
(2002)^{10}\end{array}$ & Germany & $\begin{array}{l}\text { Alpha-lipoic } \\
\text { Acid (oral) }\end{array}$ & 23 & Sniffin'Sticks test & $\begin{array}{l}\text { Oral alpha-lipoic acid appears to be effective in the treatment of post- } \\
\text { viral NCSD **. }\end{array}$ \\
\hline Reden et al. $(2012)^{24}$ & Germany & $\begin{array}{l}\text { Vitamin A } \\
\text { (oral) }\end{array}$ & 52 & Sniffin'Sticks test & $\begin{array}{l}\text { A } 10,000 \mathrm{IU} / \text { day dose for } 3 \text { months does not appear to be effective in } \\
\text { the treatment of post-viral NCSD } * * \text {. }\end{array}$ \\
\hline $\begin{array}{l}\text { Whitcroft et al. } \\
(2016)^{25}\end{array}$ & Germany & \begin{tabular}{|l}
$\begin{array}{l}\text { Sodium citrate } \\
\text { (intranasal) }\end{array}$ \\
\end{tabular} & 57 & Sniffin'Sticks test & $\begin{array}{l}\text { Intranasal sodium citrate may be beneficial for patients with post-viral } \\
\text { NCSD **. }\end{array}$ \\
\hline $\begin{array}{l}\text { Whitcroft et al. } \\
(2017)^{28}\end{array}$ & Germany & \begin{tabular}{|l} 
Sodium citrate \\
(intranasal)
\end{tabular} & 49 & Sniffin'Sticks test & $\begin{array}{l}\text { Intranasal sodium citrate may be effective for patients with post-viral } \\
\text { NCSD **. }\end{array}$ \\
\hline $\begin{array}{l}\text { Panagiotopoulos et al. } \\
(2005)^{26}\end{array}$ & Greece & $\begin{array}{l}\text { Sodium citrate } \\
\text { (intranasal) }\end{array}$ & 31 & Sniffin'Sticks test & There was an improvement in smell in $73 \%$ of patients. \\
\hline $\begin{array}{l}\text { Philpott et al. } \\
(2017)^{27}\end{array}$ & $\begin{array}{c}\text { United } \\
\text { Kingdom }\end{array}$ & $\begin{array}{l}\text { Sodium citrate } \\
\text { (intranasal) }\end{array}$ & 55 & $\begin{array}{l}\text { phenyl ethyl alcohol (roses), 1-butanol } \\
\text { (pear), acetic acid (vinegar) and eucalyptol } \\
\text { (menthol) }\end{array}$ & Sodium citrate has some potential as a treatment for NCSD **. \\
\hline Qiao et al. $(2019)^{29}$ & China & $\begin{array}{l}\text { Olfactory } \\
\text { training }\end{array}$ & 125 & Sniffin`Sticks olfactory test (TDI score*) & $\begin{array}{l}\text { Discrimination and odor identification improved after } 3 \text { and } 6 \text { months } \\
\text { of olfactory training. }\end{array}$ \\
\hline Poletti et al. $(2016)^{30}$ & Germany & \begin{tabular}{|l|} 
Olfactory \\
training
\end{tabular} & 96 & Sniffin`Sticks olfactory test (TDI score*) & $\begin{array}{l}\text { HWM training improved the odor threshold }(T) \text { in patients with post- } \\
\text { viral NCSD }(\mathrm{p}<0.01) \text {. }\end{array}$ \\
\hline $\begin{array}{l}\text { Konstantinidis et al. } \\
(1013)^{31}\end{array}$ & Greece & $\begin{array}{l}\text { Olfactory } \\
\text { training }\end{array}$ & 81 & Sniffin`Sticks olfactory test (TDI score*) & $\begin{array}{l}\text { There was an improvement in the TDI score at } 3 \text { and } 6 \text { months } \\
\text { compared to the previous visit }(\mathrm{p}<0.05) \text { in patients with post-viral } \\
\text { NCSD **. }\end{array}$ \\
\hline $\begin{array}{l}\text { Hummel et al. } \\
(2009)^{32}\end{array}$ & Germany & $\begin{array}{l}\text { Olfactory } \\
\text { training }\end{array}$ & 56 & Sniffin`Sticks olfactory test (TDI score*) & $\begin{array}{l}\text { There was a significant improvement in the TDI score in the treated } \\
\text { group }(p=0.031) \text {, but there was no analysis separated by NCSD ** } \\
\text { etiologies. }\end{array}$ \\
\hline
\end{tabular}

* Threshold (T), discrimination, (D) identification (I)

disorder. 
Table 3 Demographic data, general practitioners, olfactory-gustatory diagnostic method, prevalence of olfactory and gustatory disorders in patients in the four studies selected for meta-analysis.

\begin{tabular}{|c|c|c|c|c|c|c|c|c|c|}
\hline Author & $\mathrm{N}$ & Sex & Age & $\begin{array}{l}\text { Causes of } \\
\text { NCSD**, [n } \\
(\%)]\end{array}$ & $\begin{array}{l}\text { Olfactory } \\
\text { assessment } \\
\text { method }\end{array}$ & $\begin{array}{l}\text { TDI score } \\
\text { measurement } \\
\text { times }\end{array}$ & Olfactory therapy (odors) & $\begin{array}{l}\text { Intensity of } \\
\text { therapy }\end{array}$ & Conclusion \\
\hline Qiao et al. ${ }^{29}$ & $\begin{array}{l}\text { 125: } \\
\text { Therapy: } 65 \\
\text { Control:60 }\end{array}$ & $\begin{array}{l}21 \square \\
44 \square\end{array}$ & $\begin{array}{l}50.2 \\
( \pm 13.5) \\
\text { years }\end{array}$ & URTI*** & $\begin{array}{l}\text { Sniffin' Sticks } \\
\text { olfactory test (TDI } \\
\text { score*) }\end{array}$ & $\begin{array}{l}\text { Onset } \\
1 \text { month } \\
3 \text { months } \\
6 \text { months }\end{array}$ & $\begin{array}{l}\text { Phenyl etanol (rose), Menthol } \\
\text { (mint), Citronellal (lemon), } \\
\text { Eugenol (clove). }\end{array}$ & $\begin{array}{l}2 \mathrm{x} / \text { day for } 10 \\
\text { seconds (each } \\
\text { substance) }\end{array}$ & $\begin{array}{l}\text { Discrimination } \\
\text { (D) and odor } \\
\text { identification } \\
\text { (I) improved } \\
\text { after } 3 \text { and } 6 \\
\text { months of } \\
\text { training (p } \\
<0.05 \text { ), but } \\
\text { not the } \\
\text { threshold (T) } \\
\text { (p>0.05). }\end{array}$ \\
\hline Poletti et al. ${ }^{30}$ & $\begin{array}{l}96: \\
\text { Therapy:48 } \\
\text { Control:48 }\end{array}$ & $\begin{array}{l}24 \square \\
24 \square\end{array}$ & $\begin{array}{l}59.4 \\
( \pm 12.6) \\
\text { years }\end{array}$ & URTI*** & $\begin{array}{l}\text { Sniffin`Sticks } \\
\text { olfactory test (TDI } \\
\left.\text { score }{ }^{*}\right)\end{array}$ & $\begin{array}{l}\text { Onset } \\
3 \text { months }\end{array}$ & $\begin{array}{l}\text { Phenyl etanol (rose), Menthol } \\
\text { (mint), Citronellal (lemon), } \\
\text { Eugenol (clove). }\end{array}$ & $\begin{array}{l}2 \mathrm{x} / \text { day for } 10 \\
\text { seconds (each } \\
\text { substance) }\end{array}$ & $\begin{array}{l}\text { HWM training } \\
\text { improved odor } \\
\text { threshold }(\mathrm{T}) \\
\text { in patients } \\
\text { with post-viral } \\
\text { NCSD } \\
(\mathrm{p}<0.01) . \\
\end{array}$ \\
\hline $\begin{array}{l}\text { Konstantinidis } \\
\text { et al. }{ }^{31}\end{array}$ & $\begin{array}{l}81: \\
\text { Therapy:49 } \\
\text { Control:32 }\end{array}$ & $\begin{array}{l}21 \square \\
44 \square\end{array}$ & $\begin{array}{l}51.5 \\
( \pm 5.2) \\
\text { years }\end{array}$ & URTI*** & $\begin{array}{l}\text { Sniffin' Sticks } \\
\text { olfactory test (TDI } \\
\left.\text { score }{ }^{*}\right)\end{array}$ & $\begin{array}{l}\text { Onset } \\
3 \text { months } \\
4 \text { months }\end{array}$ & $\begin{array}{l}\text { Phenyl etanol (rose), Menthol } \\
\text { (mint), Citronellal (lemon), } \\
\text { Eugenol (clove). }\end{array}$ & $\begin{array}{l}2 \mathrm{x} / \text { day for } 10 \\
\text { seconds (each } \\
\text { substance) }\end{array}$ & $\begin{array}{l}\text { There was an } \\
\text { improvement } \\
\text { in TDI score } \\
\text { at } 3 \text { and } 6 \\
\text { months } \\
\text { compared to } \\
\text { the previous } \\
\text { visit (p <0.05) } \\
\text { in patients } \\
\text { with post-viral } \\
\text { NCSD. } \\
\end{array}$ \\
\hline
\end{tabular}

* Threshold (T), discrimination, (D) identification (I)

score.

** Non-conductive smell

disorder.

*** Upper respiratory tract infection. 
Table 4 Risk of bias assessment of the included articles.

\begin{tabular}{|c|c|c|c|c|c|c|c|}
\hline & $\begin{array}{c}\text { Random sequence } \\
\text { generation }\end{array}$ & $\begin{array}{c}\text { Allocation } \\
\text { concealment }\end{array}$ & $\begin{array}{c}\text { Blinding of participants/ } \\
\text { professionals }\end{array}$ & $\begin{array}{c}\text { Blinding of outcome } \\
\text { evaluators }\end{array}$ & $\begin{array}{c}\text { Incomplete } \\
\text { Outcomes }\end{array}$ & $\begin{array}{l}\text { Selective outcome } \\
\text { reporting }\end{array}$ & $\begin{array}{c}\text { Other sources } \\
\text { of bias }\end{array}$ \\
\hline Philpott et al. $(2017)^{27}$ & LOW & LOW & LOW & LOW & LOW & LOW & $\mathrm{HIGH}$ \\
\hline Qiao et al. $(2020)^{29}$ & UNCLEAR & UNCLEAR & UNCLEAR & UNCLEAR & UNCLEAR & LOW & LOW \\
\hline $\begin{array}{l}\text { Panagiotopoulos et al. } \\
(2005)^{26}\end{array}$ & HIGH & HIGH & UNCLEAR & UNCLEAR & LOW & LOW & LOW \\
\hline Rezaeian $(2018)^{22}$ & LOW & LOW & LOW & LOW & LOW & LOW & HIGH \\
\hline Hummel et al. $(2009)^{32}$ & UNCLEAR & UNCLEAR & HIGH & UNCLEAR & LOW & LOW & LOW \\
\hline $\begin{array}{l}\text { Gudziol; Hummel et al. } \\
(2009)^{23}\end{array}$ & UNCLEAR & UNCLEAR & UNCLEAR & UNCLEAR & LOW & LOW & UNCLEAR \\
\hline $\begin{array}{l}\text { Whitcroft et al. } \\
(2016)^{25}\end{array}$ & UNCLEAR & UNCLEAR & LOW & UNCLEAR & LOW & LOW & HIGH \\
\hline Reden et al. $(2017)^{24}$ & UNCLEAR & LOW & LOW & LOW & LOW & LOW & UNCLEAR \\
\hline Poletti et al. $(2016)^{30}$ & HIGH & LOW & UNCLEAR & UNCLEAR & LOW & LOW & $\mathrm{HIGH}$ \\
\hline $\begin{array}{l}\text { Whitcroft et al. } \\
(2017)^{28}\end{array}$ & UNCLEAR & UNCLEAR & LOW & HIGH & LOW & LOW & HIGH \\
\hline Quint et al. $(2002)^{21}$ & UNCLEAR & UNCLEAR & UNCLEAR & UNCLEAR & LOW & LOW & LOW \\
\hline $\begin{array}{l}\text { Konstantinidis et al. } \\
(2013)^{31}\end{array}$ & HIGH & UNCLEAR & HIGH & UNCLEAR & LOW & LOW & UNCLEAR \\
\hline Hummel et al. $(2002)^{10}$ & UNCLEAR & UNCLEAR & LOW & UNCLEAR & LOW & LOW & HIGH \\
\hline
\end{tabular}

\section{Figures}

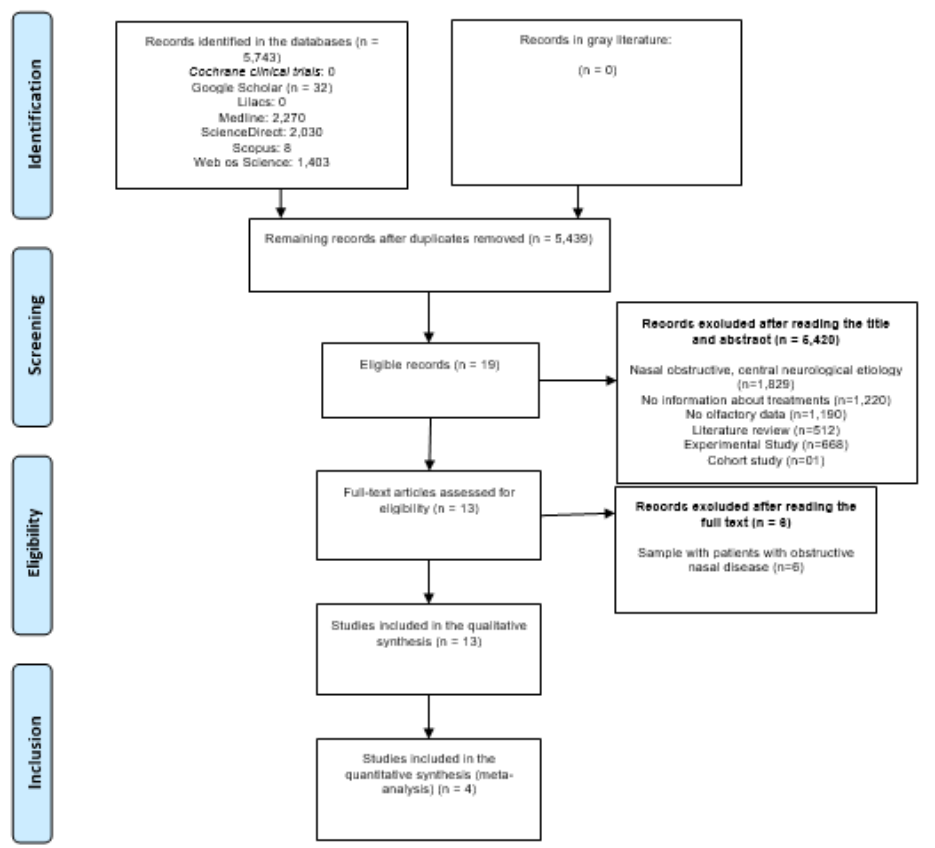

Figure 1

Identification and selection flow chart.

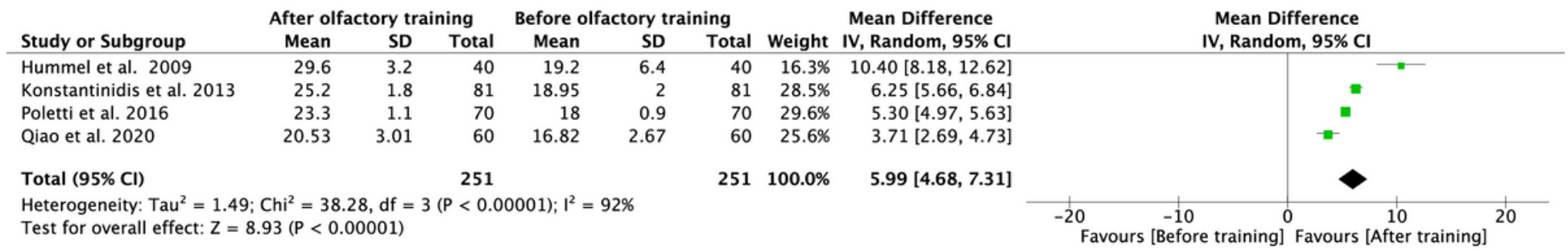

\section{Figure 2}

Olfactory training in patients with NCSD: difference in the mean of TDI score before and after training. 


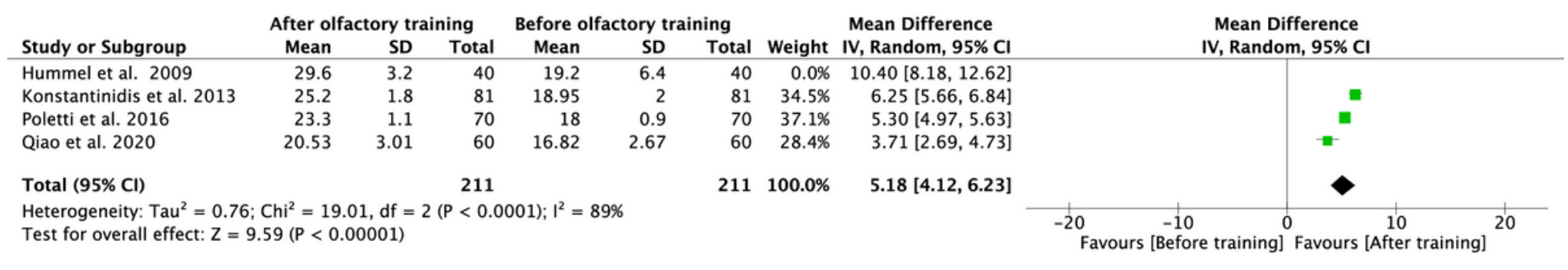

\section{Figure 3}

Olfactory training in patients with post-viral NCSD: difference in the mean of TDI score before and after training.

\section{Supplementary Files}

This is a list of supplementary files associated with this preprint. Click to download.

- Appendix1.docx 